\title{
Levels and treatment options for enteric and antibiotic resistant bacteria in sewage from Sisimiut, Greenland
}

Jensen, Pernille Erland; Gunnarsdottir, Ragnhildur; Andersen, Henrik Rasmus; Martinsen, Grith ; Stærk Nicolajsen, Ellen ; Davidsen, Steffen; Toke, Jens

Published in:

ISCORD 2013. Planning for sustainable cold regions

Publication date:

2013

Link back to DTU Orbit

Citation (APA):

Jensen, P. E., Gunnarsdottir, R., Andersen, H. R., Martinsen, G., Stærk Nicolajsen, E., Davidsen, S., \& Toke, J. (2013). Levels and treatment options for enteric and antibiotic resistant bacteria in sewage from Sisimiut, Greenland. In ISCORD 2013. Planning for sustainable cold regions (pp. 779-790). American Society of Civil Engineers.

\section{General rights}

Copyright and moral rights for the publications made accessible in the public portal are retained by the authors and/or other copyright owners and it is a condition of accessing publications that users recognise and abide by the legal requirements associated with these rights.

- Users may download and print one copy of any publication from the public portal for the purpose of private study or research.

- You may not further distribute the material or use it for any profit-making activity or commercial gain

- You may freely distribute the URL identifying the publication in the public portal 


\title{
Levels and treatment options for enteric and antibiotic resistant bacteria in sewage from Sisimiut, Greenland
}

\author{
Pernille Erland Jensen, $\mathrm{PhD}$ \\ Ragnhildur Gunnarsdottir, PhD \\ Centre of Arctic Technology, Civil Engineering, Technical University of Denmark \\ Henrik Rasmus Andersen, $\mathrm{PhD}$ \\ Grith Martinsen, BSc \\ Ellen Stærk Nicolajsen, BSc \\ Steffen Davidsen, BSc \\ Jens Toke, BSc \\ Department of Environmental Engineering, Technical University of Denmark
}

\begin{abstract}
Sewage treatment in Arctic towns is inadequate. Sewage contains pathogenic microorganisms, parasites, antibiotic resistant bacteria, and toxic compounds. Discharging of untreated sewage can thus have a negative effect on people's health and the aquatic environment in the receiving water bodies. Conventional treatment is challenging and expensive to implement in Arctic communities due to the cold climate and scattered population. In addition, advanced removal of nutrients may in many cases be overstated due to the low population density and large receiving water bodies. In this work we investigated the presence of Total coliforms, Escherichia coli (Ecoli), enterococci, streptococci, antibiotic resistant enteric bacteria, and toxicity in sewage from two sewer outlets in Sisimiut, West-Greenland, as well as in a sub-stream from the local hospital. According to the content of streptococci and enterococci, the wastewater is very strong, suggesting a potential hygienic risk. In addition, a high fraction of antibiotic resistant bacteria and an increased toxicity in the sub-stream from the hospital, suggest that this stream contains toxic compounds, possibly antibiotic of nature that may affect the local Arctic marine environment negatively. Both peracetic acid treatment and UV-C radiation shows potential for disinfection of the wastewater after removal of solids $>60 \mu \mathrm{m}$. E-coli was most susceptible to peracetic acid treatment, while a maximum possible reduction of enterococci and coliforms of 2-3 size orders was observed. The highest reduction observed by UV-C treatment was 4 size orders for enterococci, but no maximum level was observed. UV-treatment may thus be a preferred disinfection method, in particular for a community with long transport distances to the nearest chemical supplier and access to hydropower from a local hydropower plant.
\end{abstract}

KEY WORDS: Arctic, sewage, pathogens, UV-disinfection, peracetic acid.

\section{INTRODUCTION}

In Greenland no treatment of industrial or domestic sewage exists. In the towns, the majority has traditional water flush toilets, and is connected to piped sewer systems from which the sewage is led out untreated to the receiving water body directly on the coast (Gunnarsdóttir et al., 2013). In 20042005 the effects of discharging sewage to the recipients by Greenlandic towns and settlements was investigated (COWI Consultants, 2005). The results stated that the disposal is of no general concern, when discharged directly to the sea, due to low population density and large receiving 
water bodies; but also noted that if the water exchange in the receiving water body is poor, the sewage discharge can deteriorate the quality of the local marine environment and cause eutrophication (COWI Consultants, 2005). Based on these results, implementation of sewage treatment has not been considered by Greenlandic authorities until recently. However, many sewage outlets in Greenland, such as the ones in the bay Ulkebugt in Sisimiut, are placed in water bodies with low water exchange. In addition, only effects of organic matter and nutrients were evaluated in the project (COWI Consultants, 2005). Other substances in the sewage, such as heavy metals, xenobiotic compounds and pathogens were left out of the evaluation due to lack of regular measurements, and thus knowledge about their presence. Exactly those non-evaluated compounds might be of more general concern to the Arctic marine environment, and the health of the local population: It was investigated whether anthropogenic contamination in an open fjord (Ulkebugt) adjacent to the town of Sisimiut in West Greenland, which receives untreated domestic sewage, affects the fecundity (i.e. reproductive potential), reproductive success (Bach et al., 2010), and genetic diversity (Bach and Dahllöff, 2012) of the benthic amphipod Orchomenella pinguis. It turned out that $\mathrm{O}$. pinguis collected at contaminated sites in the fjord had significantly higher fecundity but also higher frequency of embryo aberrations resulting in lower fertility (i.e. actual reproductive success) compared to the individuals collected at clean sites outside the fjord (Bach et al., 2010). Further, populations from contaminated sites in the fjord had increased tolerance towards known stressors, and cost towards unknown stressors (Bach and Dahllöff, 2012). Ambiguous results were obtained concerning genetic diversity, explained by migration events (Bach and Dahllöff, 2012). Analyses of heavy metals in sediment samples from Sisimiut Harbor also revealed that the upper $0-1 \mathrm{~cm}$ of the sediment contains higher levels of heavy metals than in 1-3 cm depth, the highest levels being found close to sewage outlets and in the waterway into the industrial harbor (Villumsem and Ottosen, 2006). Concerning the bacteriological risk of discharging untreated sewage to the recipients in Greenland, it was pointed out that special care should be taken with sewage discharge in localities where food is being processed, either on or near the sea (COWI Consultants, 2005). In Sisimiut a fishing threshold has been established well outside the bay of Ulkebugt to avoid contamination of food, but this threshold is placed no more than $1000 \mathrm{~m}$ west of another main sewage outlet. In addition to that a risk of spread occurs when fish and sea mammals are transported into the harbor in the bay and processed on shore, and when local people practice sea sports like kayaking in the bays. It may also be suspected that, depending on meteorological factors, pathogens may spread as bioaerosols (Korzeniewska, 2011), and pose a direct health threat to the local population; in particular due to the placement of the sewage outlets above the water line.

Conventional treatment is challenging and expensive to implement in Arctic communities due to the cold climate and scattered population. This has also been recognized by e.g. the Canadian Council of Ministers of the Environment (CCME) when they developed the Municipal Wastewater Effluent Strategy in 2009, in which it was identified that the Far North, due to its extreme climatic conditions and remoteness, require particularly careful consideration (Canadian Council of Ministers of the Environment, 2009). For the same reasons the municipality of Qeqqata in which Sisimiut is placed, decided to investigate the possibility of installing primary treatment of their sewage in Sisimiut, possibly succeeded by some means of hygienization. Primary treatments considered are either a sedimentation tank or an $\mathrm{Al}-2^{\circledR}$ separation system, which is originally developed for treatment of agricultural and production sewage by chemical and mechanical treatment. UV-treatment and peracetic acid treatment have earlier been suggested and used as methods for disinfection of sewage (Hunter and Townsend, 2010; Kitis, 2004). Peracetic acid reacts with macromolecules in the cell and thereby destroys the structure of the cell wall and larger structures inside the cell such as proteins, lipids and nucleic acids (McDonnell, 2007). It is as 
efficient a disinfectant as the commonly used hypochlorite (Kitis, 2004). It is advantageous over other chemical methods in that it does not produce toxic degradation products like e.g. hypochlorite does. It is relatively stable and easy to handle compared to performic acid (Heinonen-Tanski and Miettinen, 2010). Peracetic acid disinfection works at low temperatures, although efficiency increases with temperature (Kitis, 2004). UV treatment works by transferring electromagnetic radiation to the genetic material of the organisms, which thereby loses their ability to reproduce (McDonnell, 2007; US EPA, 1999). Apart from the genetic material, the UV-light also influences membranes and proteins, to further disrupt the organisms (McDonnell, 2007). It is known that UVtreatment is strongly influenced by the presence of particulates in the water phase, and treatment of black sewage requires much higher doses compared to treatment of grey water or drinking water (Winward et al., 2008). Still, however, with long transport distances to the nearest chemical supplier, and access to hydropower from local hydropower plants, UV-treatment may be a preferential disinfection method in several Greenlandic towns with one major modification: In commercially available UV-plants, the UV-lamps are submerged in the stream of water to be treated. This is an advantage for relatively clean water, however for sewage, problems with adhesion of fats and particles on the lamps may occur, why a setup with the lamp above the surface may be preferred.

The aim of this work was to contribute to the knowledge and awareness about presence of pathogens and antibiotic resistant bacteria in raw sewage in Greenland, and to test simple and cheap methods for disinfection of the sewage, that are applicable in small Arctic communities. We did that by analyzing the level of total coliforms, Escherichia coli (E-coli), streptococci, enterococci, and selected antibiotic resistant enteric bacteria in sewage from two sewage outlets and a sub stream from the local hospital in Sisimiut. The overall toxicity to a marine species was tested, and laboratory scale experiments on disinfection by UV-radiation and peracetic acid treatment were made.

\section{MATERIALS AND METHODS}

\subsection{Locations}

The town of Sisimiut is a developing town with a bit more than 6,000 inhabitants situated on the West-coast of Greenland $66^{\circ} 55^{\prime}$ north and 53 $40^{\prime}$ west approximately $40 \mathrm{~km}$ north of the polar circle. It is the second largest town in Greenland. Approximately 78\% of the households are connected to sewer while $10 \%$ have a sludge tank and $12 \%$ bag toilets. A map of the sewered areas is found in figure 1. Samples were taken from the main outlet in the bay Ulkebugt outlet (A), which serve 1560 people including the hospital; from a sub stream including only the hospital sewage (B), and from the largest sewer outlet (C), serving around 1680 persons, which is also the outlet closest to the fishing threshold. For comparison, a sample (D) from the Danish wastewater treatment plant "Lundtofte" (135.000 PE), north of Copenhagen, was used.

\subsection{Sampling and storage}

In 2011 a $1 \mathrm{~L}$ sample was taken at sampling points $\mathrm{A}, \mathrm{B}$ and $\mathrm{C}$, morning, noon and afternoon on a normal weekday in August, and the three samples from each point were mixed. Subsamples for 
analysis of $\mathrm{P}$ were filtered through a $0,45 \mu \mathrm{m}$ filter, and subsamples for $\mathrm{P}$ and $\mathrm{N}$ were conserved by addition of $1 \mathrm{~mL} \mathrm{H}_{2} \mathrm{SO}_{4} / 100 \mathrm{~mL}$ sample (US EPA, 1982). Samples were stored in refrigerator below $4^{\circ} \mathrm{C}$, and all microbial analyses were initiated within 30 hours after sampling. The only exception were subsamples for the biotox test, which were stored frozen for a week. In 2012, samples were collected from sampling points A and D. The sample from sampling point A was collected on a normal weekday in August by taking five 15L samples with two hours intervals during the day, and mixing all samples into one. The mixed sample was filtered through a $60 \mu \mathrm{m}$ filter and stored in refrigerator below $4^{\circ} \mathrm{C}$ till use. The sample from sampling point $\mathrm{D}$ was collected in October 2012, by immersing a bucket into the stream from the inlet to the plant. The sample was filtered through a $60 \mu \mathrm{m}$ filter into a $25 \mathrm{~L}$ canister, and taken directly to the laboratory for experiments and analysis on the same day.

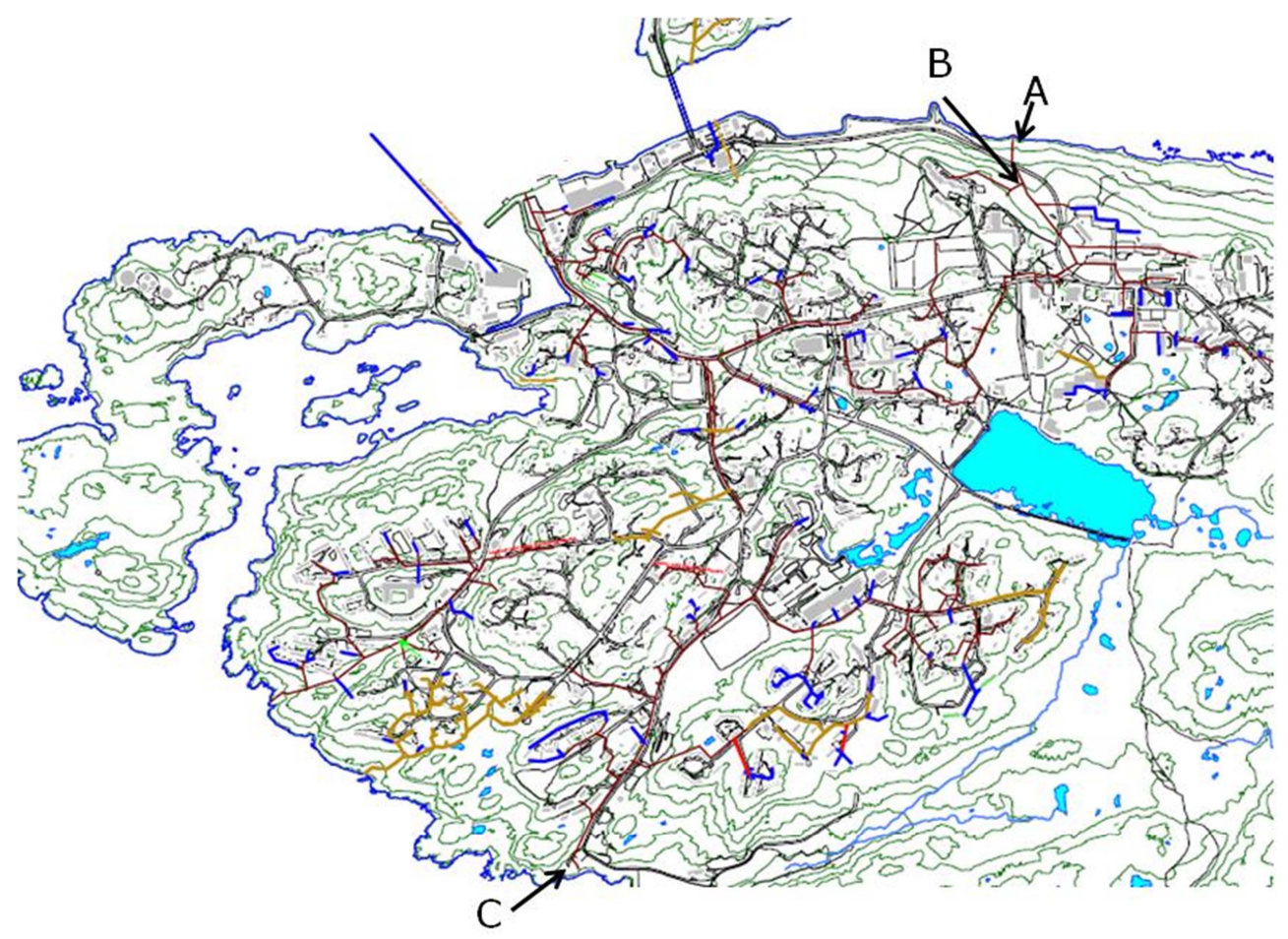

Figure 1: Sisimiut town with sewering and sampling locations A, B and C.

\subsection{Analysis}

\subsubsection{Analysis of $P, N$ and $C O D$}

Total $\mathrm{N}$ was analyzed by Kjeldahl destruction and titration (duplicate analysis in 2011, triplicate in 2012). Dissolved P was analyzed in duplicate (2011) or triplicate (2012) by ICP-OES (2011). Chemical oxygen demand (COD) was analyzed in triplicate according to Danish Standard Method DS 217:1991 "Water examination. Determination of chemical oxygen demand COD $_{\mathrm{Cr}}$ with dichromate" by destruction of the samples at $148^{\circ} \mathrm{C}$ for 110 minutes in sulfuric acid in presence of excess $\mathrm{Cr}^{6+}$ with silversulfate as a catalyst. The remaining $\mathrm{Cr}^{6+}$ was determined by titration with 
ferroammoniumsulfate (FAS) added redox indicator 1,10-fenantrolin(o-fenantrolin) that shifts from clear greenish to rusty red when $\mathrm{Cr}^{6+}$ is reduced.

\subsubsection{Analysis of coliforms, E-coli, streptococci and enterococci}

On all samples taken in 2011, analyses were made according to (Eaton et al., 2005). Triplicate experiments were performed and most probable number (MPN) values were calculated from the number of positive tubes as described in (Blodgett, 2010). At each enumeration step, the samples were diluted 10 -fold with $0.9 \% \mathrm{NaCl}$ by manual shaking and with a mini shaker at medium speed before transfer to the different growth media. For the analyses of total coliforms, lauryl sulphate (LS) broth was used as growth medium for the presumptive phase and brilliant green lactose bile (BG) broth for the confirmed phase. Both media were incubated at $37^{\circ} \mathrm{C}$ for $48 \pm 3 \mathrm{~h}$. Tryptone water and Kovac's reagent were used for confirmation of E-coli. Both growth media were incubated at $45^{\circ} \mathrm{C}$ for $24 \pm 2 \mathrm{~h}$. Growth media for the presumptive phase of analyses of fecal Streptococci was azide dextrose (AD) broth, and Pfizer selective enterococci (PSE) agar was used for the confirmed phase. Tubes containing AD broth were incubated for $48 \pm 3 \mathrm{~h}$ at $37^{\circ} \mathrm{C}$ while the PSE agar plates were incubated for $24 \pm 2 \mathrm{~h}$ at $37^{\circ} \mathrm{C}$. Brownish-black colonies with brown halos on the PSE agar plates confirmed the presence of fecal streptococci. To confirm whether the fecal Streptococci belonged to the Enterococci group the colonies were transferred into brain-heart infusion (BHI) broth containing $6.5 \% \mathrm{NaCl}$ and incubated at $45^{\circ} \mathrm{C}$ overnight. On samples taken in 2012 , analyses were made by use of reagents Colilert-18 (coliforms and E-coli) and Enterolert (enterococci) from IDEXX $^{\circledR}$ and IDEXX Quanti-tray $2000^{\circledR}$ sealer. Colilert-18 samples were incubated at $35^{\circ} \mathrm{C}$ for $18 \mathrm{~h}$ and Enterolert samples were incubated at $42^{\circ} \mathrm{C}$ for $24 \mathrm{~h}$. Most probable numbers in a range between 1 and 2420 bacteria/mL could be detected, and dilution series were made accordingly. For identification of coliforms, the yellow samples were counted. For identification of E-coli and enterococci, the samples were subjected to UV-light and fluorescent samples were counted.

\subsubsection{Analysis of antibiotic resistant bacteria}

Occurrence of antibiotics resistance was tested for three different antibiotics used on a regular basis in Sisimiut: Tetracycline, amoxicillin and ceftriaxon. Antibiotic resistant enteric bacteria were enumerated using MacConkey agar which is selective for enterobacteriaceae. Stock solutions of the antibiotics were prepared with appropriate solvents, and stored at $-20^{\circ} \mathrm{C}$ prior to use. The antibiotic stock solutions were inoculated into the fluid sterilized agar at a temperature below $50^{\circ} \mathrm{C}$ to obtain the following concentrations: $50 \mu \mathrm{g} / \mathrm{mL}$ amoxicillin, $1 \mu \mathrm{g} / \mathrm{mL}$ ceftriaxon, $10-15 \mu \mathrm{g} / \mathrm{mL}$ tetracycline. The inverted plates were incubated at $37^{\circ} \mathrm{C}$ for $2-4$ days, until countable colonies had grown.

\subsubsection{Analysis of Toxicity}

The toxicity was tested by the BIOTOX-LUMNISCENCE method on the marine bacteria $V$. fischeri (ISO Standard 11348-3, 2007). A freeze dried tablet with the bacteria was suspended in $12.5 \mathrm{ml} \mathrm{2 \%} \mathrm{NaCl-solution} \mathrm{and} \mathrm{acclimated} \mathrm{to} \mathrm{room} \mathrm{temperature} \mathrm{for} \mathrm{half} \mathrm{an} \mathrm{hour.} \mathrm{The} \mathrm{salinity} \mathrm{of} \mathrm{the}$ samples was adjusted to $2 \%$ with $\mathrm{NaCl}$. Because turbidity can absorb emitted light, both a filtered and an unfiltered sample were tested, and both in duplicate. The samples were diluted to 50, 25 and $12.5 \%$ in $2 \% \mathrm{NaCl}$. For the test, $100 \mu \mathrm{l}$ bacteria suspension was added to each test vial and the vials were placed in the luminometer. For control, the luminescence was measured to the time $t=0$. Immediately after this measurement, $100 \mu 1$ of $2 \% \mathrm{NaCl}$ solution was added to the controls and $100 \mu \mathrm{l}$ of test solution was added to the test vials. The luminescence of the samples was measured after 10 and 20 minutes (ISO Standard 11348-3, 2007). 


\subsection{Hygienization experiments}

\subsubsection{Experimental UV-hygienization}

A UV-treatment system was built by mounting a $15 \mathrm{~cm}$ wide box of stainless steel in a polypropylene tank, and sealing of contact points with silicone. $14 \mathrm{~cm}$ above the stainless steel surface, a 6W UV-C lamp was mounted. The filtered material was poured into a HETO ${ }^{\circledR}$ basin and pumped into one side of the stainless steel box in the UV-system by a HETO ${ }^{\circledR}$ pump, allowed to flow over the stainless steel surface at shallow depth $(1.5-2.5 \mathrm{~mm})$ while subjected to UV-radiation, and collected at the other side of the box after reaching a depth of $14-16 \mathrm{~cm}$. Sketches and pictures of the system can be seen figure 2. UV-disinfection experiments were made at room temperature the day after collection of the sewage.
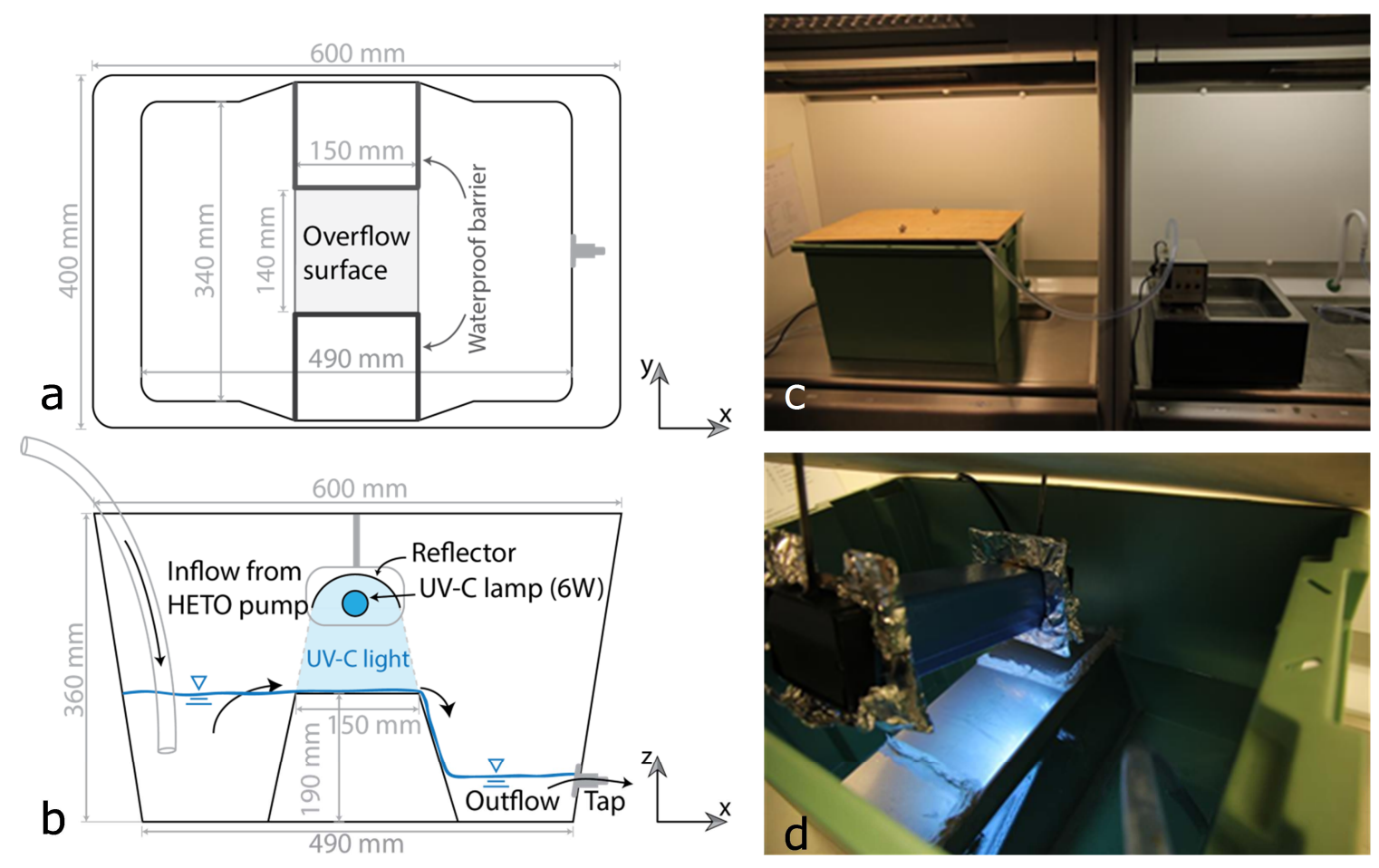

Figure 2: UV-treatment system seen from above (a), and side (b). Photograph of whole system incl. HETO pump (c) and interior of UV treatment tank (d).

Experiments were made with three doses of UV-radiation $\left(18,23,26\right.$ and $\left.37 \mathrm{~mJ} / \mathrm{cm}^{2}\right)$. All UVexperiments were made in triplicate. The doses were changed by changing the flow speed of the pump. Samples of the treated water were taken into a glass beaker through a tap and a tube. Immediately after sampling, dilutions were made for microbial analysis according to the procedure described in 2.3.3.

\subsubsection{Experimental hygienization by peracetic acid}

$100 \mathrm{~mL}$ filtered sewage was poured into $250 \mathrm{~mL}$ conical glass beakers and placed on a magnetic stirrer. Experiments were made with 4 different concentrations of peracetic acid $(5,10,25$ and 50 $\mathrm{mg} / \mathrm{L}$ ). Reaction was allowed for 15 hours, after which dilutions were made for microbial analysis according to the procedure described in 2.3.3. All experiments were made in triplicate at room temperature two days after collection of the sewage. 


\section{RESULTS AND DISCUSSION}

\subsection{Sewage characteristics}

Characteristics of the sewage are listed in table 1. The Sisimiut sewage was in general medium to high in nitrogen, while low to medium in inorganic $\mathrm{P}$ (Tchobanoglous and Burton, 1991), probably reflecting the almost fully developed transition to use of detergents without phosphorous in Greenland. The COD illustrates a weak to medium sewage in the sample from Sisimiut, while the sample from Lundtofte, Denmark was medium (Tchobanoglous and Burton, 1991).

Table 1: Analytical results of total N, total $\mathrm{P}$ and COD for sewage samples from three locations in Sisimiut (A, B and C), and from the Danish sewage treatment plant "Lundtofte".

\begin{tabular}{lccc} 
Sampling point and time & $\begin{array}{c}\mathrm{N}_{\text {Total }} \\
(\mathrm{mg} / \mathrm{L})\end{array}$ & $\begin{array}{c}\mathrm{P}_{\text {dissolved }} \\
(\mathrm{mg} / \mathrm{L})\end{array}$ & $\begin{array}{c}\mathrm{COD} \\
(\mathrm{mg} / \mathrm{L})\end{array}$ \\
\hline Sisimut A 2011 & 77 & 3.7 & $\mathrm{NA}$ \\
\hline Sisimut A 2012 & 30 & 3.2 & 143 \\
Sisimut B 2011 & 130 & 8.1 & $\mathrm{NA}$ \\
Sisimut C 2011 & 46 & 6.8 & $\mathrm{NA}$ \\
Lundtofte 2012 & 56 & 9.9 & 170
\end{tabular}

\subsection{Bacteria level in sewage}

According to the number of coliforms (figure 3), the collected wastewater was very weak in all cases (Tchobanoglous and Burton, 1991). This is surprising for the Greenlandic wastewater, as here the sewage is not diluted by rainwater, which runs in separate surface ditches. In opposition, the content of fecal streptococci and enterococci was very high in all cases compared to average wastewater (Tchobanoglous and Burton, 1991). Apart from a low number of E-coli in the hospital outlet (B), the levels of the various organisms did not vary significantly among samples, and confidence intervals overlap. Total coliforms, fecal streptococci and enterococci seemed a bit higher in the sub stream from the hospital (B) than in the Ulkebugt outlet (A), possibly reflecting the effect of dissolution of the hospital sewage by domestic sewage. The highest concentrations of Total coliforms and E-coli was, however, observed in outlet C with only domestic sewage, and for $E$-coli, the lowest value was observed in the hospital outlet (B). 


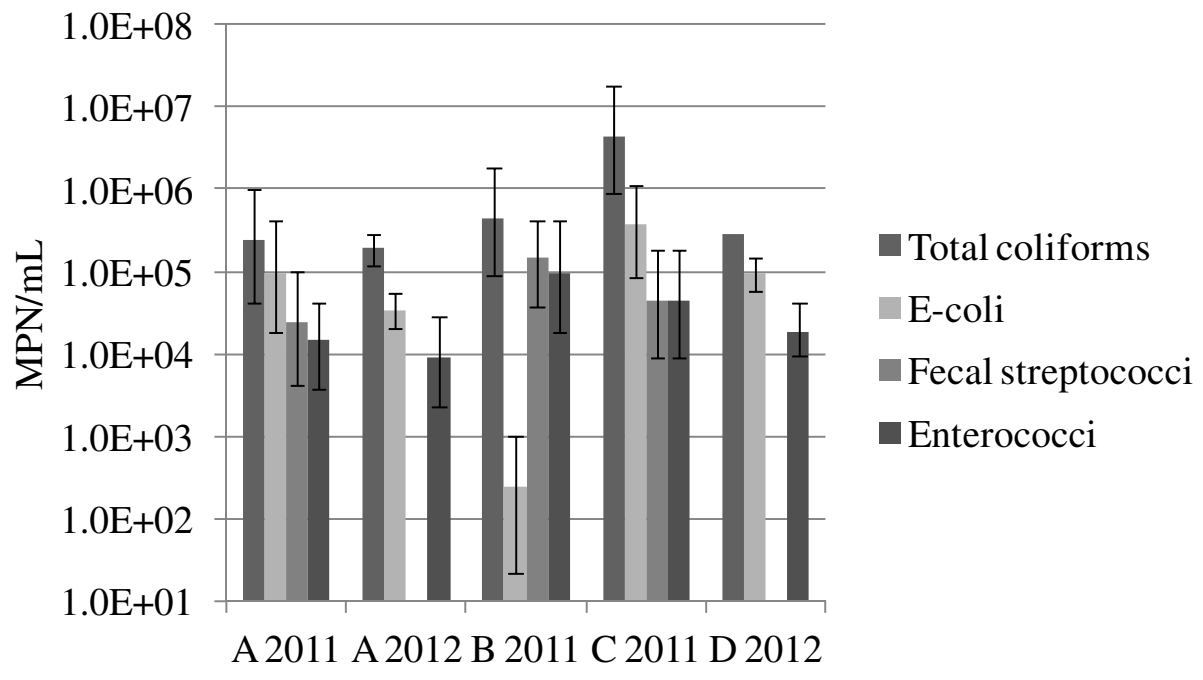

Figure 3: Enteric bacteria in sewage from the three locations (A, B and C) in Sisimiut, and from Danish sewage treatment plant "Lundtofte" (MPN/mL). T-bars indicate the $95 \%$ confidence intervals of the MPN-method. Fecal streptococci were not analyzed in 2012.

For all three antibiotic resistant groups (table 3), the level was higher in the substream from the hospital (B) than in sample from the Ulkebugt outlet (A), although the difference was almost negligible for ampicillin resistant bacteria. For both ampicillin and ceftriaxon resistant bacteria the level was, however, even higher in outlet $\mathrm{C}$ with only domestic sewage. Only for tetracycline resistant bacteria the level was higher in the substream form the hospital (B) compared to both the domestic streams. The data supports the fact that most pharmaceuticals are taken in private homes (Le Corre et al., 2012), and shows that a focused effort on treatment of hospital sewage altogether will not eliminate problems with pathogenic and resistant bacteria in the environment just as hospitals are not a major source of pharmaceuticals into the environment (Le Corre et al., 2012). When turning the attention to the fraction of the bacteria carrying resistance rather than total numbers, a pronounced higher fraction of resistant bacteria was, however, observed in the hospital sub stream (B), compared to outlets $\mathrm{A}$ and $\mathrm{C}$, possibly illustrating how presence of higher concentrations of pharmaceuticals (Le Corre et al., 2012) in hospital wastewater may result in reduction of the number of non-resistant bacteria.

Table 3: Antibiotic resistant bacteria in sewage from the three locations (A, B and C) in Sisimiut.

\begin{tabular}{ccccccc}
\hline Location & \multicolumn{2}{c}{ Ampicillin resistance } & \multicolumn{2}{c}{ Tetracycline resistance } & \multicolumn{2}{c}{ Ceftriaxon resistance } \\
\hline & CFU/ml & $\%$ & CFU/ml & $\%$ & CFU/ml & $\%$ \\
\hline Sisimut A 2011 & $2.0 \cdot 10^{5}$ & $10-17$ & $1.8 \cdot 10^{4}$ & $1-2$ & $1.1 \cdot 10^{5}$ & $6-9$ \\
Sisimut B 2011 & $2.1 \cdot 10^{5}$ & $31-39$ & $2.5 \cdot 10^{5}$ & $36-47$ & $4.6 \cdot 10^{5}$ & $67-86$ \\
\hline Sisimut C 2011 & $4.1 \cdot 10^{6}$ & NA & $2.5 \cdot 10^{4}$ & $<9$ & $9.0 \cdot 10^{5}$ & NA \\
\hline
\end{tabular}

\subsection{Toxicity}


The highest values obtained after 10 and 20 minutes of reaction in the toxicity test are illustrated in figure 4. For outlets A and B the highest values were observed after 20 minutes, while for outlet C they were observed after 10 minutes. All samples show a toxic effect on the marine species from both filtered and unfiltered samples. For outlet A the highest toxicity was observed in the filtered sample, while for both outlet B and C the highest value was observed in the unfiltered sample. The toxicity of sample A was, however, low in both cases.

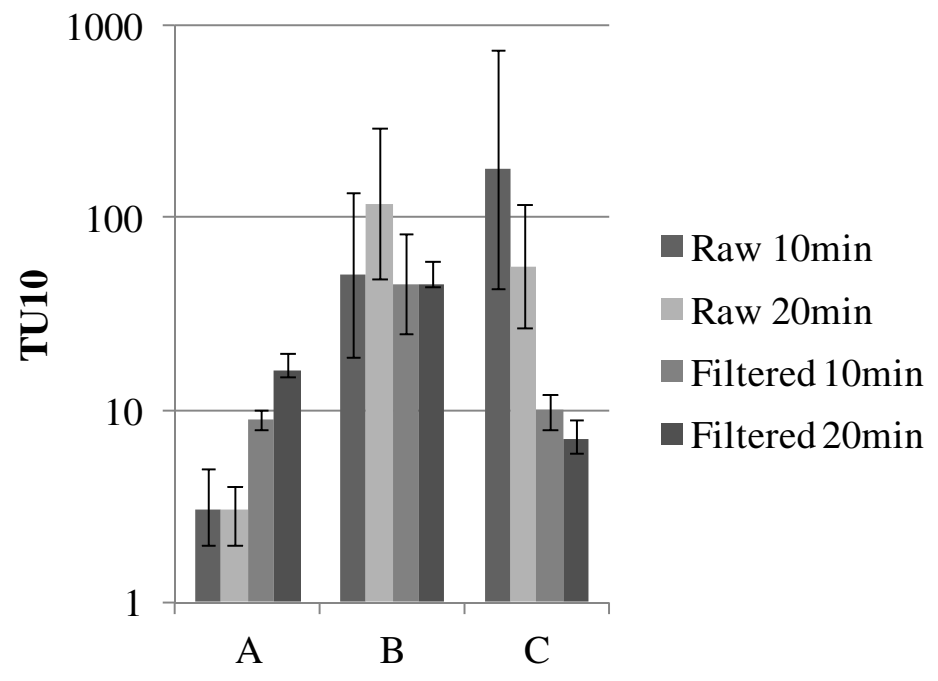

Figure 4: Toxicity of sewage from the three locations A, B and C in Sisimiut $(\%)\left(\mathrm{TU}_{10}=1 / \mathrm{EC}_{10}\right.$ is the dilution necessary to reach a toxicity of $10 \%$ effect on the tested organism).

The cause of the higher toxicity of the hospital sewage (B) and sewage from outlet $\mathrm{C}$ is unknown, however the toxicity of the hospital wastewater may be likely to origin from high concentrations of pharmaceuticals including antibiotics as suggested above.

\subsection{Disinfection experiments}

Results of the peracetic acid disinfection (a) and UV-C disinfection experiments are seen in figure 4. Both methods show ability to reduce the number of gram negative as well as gram positive bacteria by several orders of magnitude. A maximum reduction of two to three size-orders seems to be reached for coliforms and enterococci by concentrations above $25 \mathrm{mg} / \mathrm{L}$ peracetic acid, while $E$ coli are reduced more than 6 size orders. Enterococci could be reduced more than four size-orders by a UV-dosage of $37 \mathrm{~mJ} / \mathrm{cm}^{2}$, and higher reduction maybe possible if dosage is increased further. Dosages of up to several hundreds of $\mathrm{mJ} / \mathrm{cm}^{2}$ are not uncommon in water treatment (Dodd, 2012) 

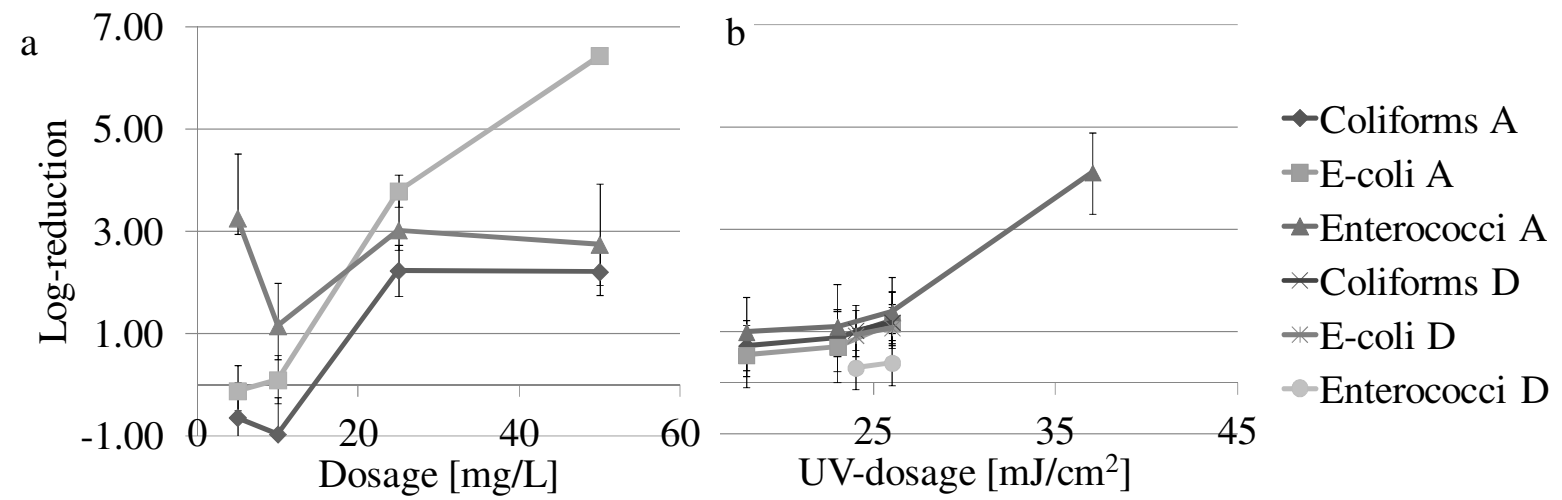

Figure 5: Results of peracetic acid disinfection (a) and UV-C disinfection (b) of raw, filtered sewage from Sisimiut (A); and UV-C disinfection of raw, filtered sewage from "Lundtofte" (D) (b). Error bars indicate lower and upper reduction limits observed from counts of five plates with different dilutions.

UV-radiation and peracetic acid disinfection react by interaction with DNA, thus both methods can be expected to reduce the amount of antibiotic resistant genes spread into the environment to the same level as the reduce pathogens and other microorganisms. An important factor to take into account is, however, the ability of UV-irradiated bacteria to undergo dark or light repair (Dodd, 2012).

Implementation of a sedimentation tank or an $\mathrm{Al}-2^{\circledR}$ separation system succeeded by UV-treatment for disinfection seem to be potent methods for handling of sewage in Arctic communities with a sufficient source of energy such as hydropower. One important issue to solve prior to large scale implementations is handling of the sludge of the primary treatment. A method suited for the local conditions must be developed in order to avoid adverse effects from handling of this material.

\section{CONCLUSION}

The outlet of untreated wastewater directly on the coast above the water line constitutes a potential health risk for the local population in Sisimiut and other Arctic communities with similar installations. According to COD, P, N and coliforms the Sisimiut wastewater is weak to medium. However, when it comes to content of streptococci and enterococci, the wastewater is very strong, suggesting a potential hygienic risk. The sub-stream from the hospital does not seem to constitute an increased hazard to health or environment when looking at bacterial numbers, however, the high fraction of antibiotic resistant bacteria in this sub-stream and the increased toxicity suggests that this stream contains toxic compounds, possibly antibiotic of nature that may affect the local Arctic marine environment negatively. Both peracetic acid treatment and UV-C radiation show potential for disinfection of the wastewater after removal of solids $>60 \mu \mathrm{m}$. E-coli were most susceptible of peracetic acid treatment, while a maximum possible reduction of enterococci and coliforms of two to three size orders was observed. The highest reduction observed for UV-C treatment was 4 size orders for enterococci, and no maximum level was observed. UV-treatment may thus be a preferred disinfection method for a community with long transport distances to the nearest chemical supplier and access to hydropower from a local hydropower plant. Further studies should be made to document the effect of UV-C treatment at higher dosages for organisms other than enterococci. A 
method for handling of the sludge of the primary treatment suited for the local conditions must be developed prior to large scale implementation.

\section{REFERENCES}

Bach, L. and Dahllöff, I. 2012, Local contamination in relation to population genetic diversity and resilience of an arctic marine amphipod. Aquatic Toxicology, 114-115, 58-66.

Bach, L., Fischer, A. and Strand, J. 2010, Local anthropogenic contamination affects the fecundity and reproductive success of an Arctic amphipod. Marine Ecology Progress Series, 419, 121-128.

Blodgett, R.: 2010, Appendix 2: Most probable Number from Serial Dilutions, Bacteriological Analytical Manual, U.S.Food and Drug Administration.

Canadian Council of Ministers of the Environment. 2009. Canada-wide Strategy for the Management of Municipal Wastewater Effluent.

COWI Consultants. 2005. Udrednings- og pilotprojekt vedrørende håndering af miljфproblemer som følge af spildevand i de grønlandske byer. Fase 2, Katalog over tekniske lфsningsmligheder (in Danish). Miljøstyrelsen (Danish EPA).

Dodd, M. C. 2012, Potential impacts of disinfection processes on elimination and deactivation of antibiotic resistance genes during water and wastewater treatment. Journal of Environmental Monitoring, 14, 1754-1771.

Eaton,A.D., Clesceri,L.S., Rice,E.W., Greenberg,A.E. and Franson,M.A.H.: 2005, Standard methods for the examination of water and wastewater, American Public Health Association, Washington D.C..

Gunnarsdóttir, R., Jenssen, P. E., Jensen, P. E., Villumsen, A. and Kallenborn, R. 2013, A review of wastewater handling in the Arctic with special reference to pharmaceuticals and personal care products (PPCPs) and microbial pollution. Ecological Engineering, 50, 76-85.

Heinonen-Tanski, H. and Miettinen, H. 2010, Performic Acid As a Potential Disinfectant At Low Temperature. Journal of Food Process Engineering, 33, 1159-1172.

Kitis, M. 2004, Disinfection of wastewater with peracetic acid: a review. Environment International, 31, 47-55.

Korzeniewska, E. 2011, Emission of bacteria and fungi in the air from wastewater treatment plants - a review. Frontiers in Bioscience, S3, 393-407.

Le Corre, K. S., Ort, C., Kateley, D., Allen, B., Escher, B. I. and Keller, J. 2012, Consumptionbased approach for assessing the contribution of hospitals towards the loads of pharmaceutical residues in municipal wastewater. Environment International, 2012, 99-111. 
McDonnell, G.: 2007, Biocides: Modes of Action and Mechanisms of Resistance, Disinfection and Decontamination, CRC Press, pp. 88-120.

Singh, C., Chaudhary, R. and Thakur, R. S. 2011, Performance of advanced photocatalytic detoxification of municipal wastewater under solar radiation - A mini review. International Journal of Energy and Environment, 2, 337-350.

Tchobanoglous, G. and Burton, F. L.: 1991, Wastewater characteristics, Wastewater Engineering Treatment, Disposal, and Reuse, pp. 47-192.

US EPA. 1982. Handbook for sampling and sample preervation of water and wastewater. EPA600/4-82-029Ohio, United States Environmental Protection Agency, environmental monitoring and support laboratory.

US EPA: 1999, Wastewater Technology Fact Sheet Ultraviolet Disinfection.

Vilhunen, S. and Sillanpää, M. 2010, Recent developments in photochemical and chemical AOPs in water treatment: a mini-review. Reviews in Environmental Science and Biotechnology, 9, 323330.

Villumsem,A. and Ottosen,L.: 2006, 'Heavy metal and TBT contamination in the sediment around Sisimiut, Greenland', pp. 21-23.

Winward, G. P., Avery, L. M., Stephenson, T. and Jefferson, B. 2008, Ultraviolet (UV) disinfection of grey water: particle size effects. Environmental Technology, 29, 235-244. 